\section{The Effect of Price, Land Area and Production Costs on Rice Farmer's Income: Case in Bone Bolango Regency}

Karsum Usman ${ }^{1}$, Usman Moonti ${ }^{2}$, Sri Endang Saleh ${ }^{3}$

${ }^{1}$ Economic Faculty, Universitas Negeri Gorontalo, Indonesia

${ }^{2}$ Economic Faculty, Universitas Negeri Gorontalo, Indonesia

${ }^{3}$ Economic Faculty, Universitas Negeri Gorontalo, Indonesia

\section{Email: karsumusman0312@gmail.com}

Abstract: This study aims to determine the effect of price, land area and production costs on the income of rice farmers in North Toto Village, Tilongkabila District, Bone Bolango Regency. Data collection techniques used in this study were observation, interviews, questionnaires, and documentation. With a total sample of 44 farmers in North Toto Village. This research method uses a quantitative approach with multiple linear regression model analysis. The results showed that the price had a negative and insignificant effect on the income of rice farmers in North Toto Village. This means that every $1 \%$ increase in price can reduce income by 0.237. Land area has a positive and significant effect on the income of rice farmers in North Toto Village. This means that every $1 \%$ increase in land area can increase income by 0.682 . Production costs have a negative and significant effect on the income of rice farmers in North Toto Village. This means that every $1 \%$ increase can reduce income by -0.254 . The coefficient of determination ( $R$ Square) is 0.596 , this shows that the percentage of rice farmers' income variation which is explained by the variation of the independent variables, namely price, land area and production costs is $59.6 \%$ for the remaining $40.4 \%$ influenced by other variables.

Keywords: Farmer's Income; Price; Land Area; Production Cost
Article History:

Received on 10 Jan 2022

Revised on 12 Jan 2022

Accepted on 15 Jan 2022

Doi: 10.37479

Indexing:

Google Scholar; Asean

Citation

Index; Copernicus; SINTA

5 (Science And

Technology Index)

The journal allows the authors to hold the copyright without restrictions and allow the authors to retain publishing rights without restrictions. international license.

\title{
INTRODUCTION
}

The agricultural sector in the concept of national income by business field or agricultural sector in a broad sense. In Indonesia, the agricultural sector in a broad sense is selected into 5 sub-sectors. Of the five sub-sectors, the food crops sub-sector is the sub-sector that can provide the largest contribution, where food crops as a producer of raw materials have succeeded in increasing farmers' income and expanding employment opportunities.

The agricultural sector is one sector that plays an important role in the economy. In Indonesia, the development of the agricultural sector is directed at increasing agricultural production in order to meet domestic food and industrial needs, increase farmers and expand job opportunities (Kuncoro, 2010). Agricultural development is directed at increasing agricultural production to meet food needs and domestic industrial needs, increasing exports, increasing farmers' income, expanding job opportunities, and encouraging equal distribution of business opportunities (Amir Machmud, 2016).

Agriculture is one of the activities that are useful in terms of resources carried out by humans to be able to produce food, raw materials, energy sources and activities that aim to manage their environment. The agricultural sector is divided into several sub-sectors of plantation, forestry, animal husbandry, fisheries and food crops. Since the beginning of the agricultural sector there is no need to doubt its development, agriculture is supported by the quality of human resources who can take advantage of natural resources in the form of rice plants. 
In Gorontalo Province, the agricultural sector is the leading sector which has an important role in the economy. Rice field harvested area in Gorontalo Province is 48686.34 (ha) for 2020. Productivity is 46.75 (ku/ha) for 2020. Production is 227627.20 (tons) for 2020. (Central Bureau of Statistics, 2020).

Bone Bolango Regency is a rice-producing area in Gorontalo Province, currently Bone Bolango Regency has 18 sub-districts, one of which is Tilongkabila sub-district where most of the population are lowland rice farmers. The area of lowland rice is 56.061 ha and production is 289.656 tons (productivity $51.67 \mathrm{kw} / \mathrm{ha}$ ), with the largest harvested area in Gorontalo Regency at 25.104 ha. For upland rice is 38 ha with a production of 120 tons (productivity $31.58 \mathrm{kw} / \mathrm{ha}$ ). Corn harvested area is 140,460 ha with 677,249 tons of production (48.22 kw/ha productivity), $48 \%$ of which is in Pohuwato Regency. Gorontalo City with a land area of 916 ha with a productivity of 6.1 tons, North Gorontalo Regency with a land area of 5,866 ha (Department of Agriculture of Gorontalo Province, 2020). The harvested area in 2019 reached 4,781 ha with a productivity achievement of 5.02 tons of harvested dry grain. For 2020, with a land area of 4,913 ha, productivity gains an average of 6.23 tons of dry grain harvested. (Gorontalo ANTARA, 2020).

The development of the agricultural sector is expected to increase farmers' income as expected. Because income is a measuring tool in assessing the success or failure of a business, the size of the income earned by the residents of North Toto Village is influenced by the receipt of production costs. North Toto Village is one of the villages in Tilongkabila District, Bone Bolango Regency.

Table 1. Land area, production and number of rice farmers in North Toto Village in 2016-2020

\begin{tabular}{|c|c|c|c|}
\hline Year & Land Area & Production & Farmers \\
\hline 2016 & 111,6 & - & 50 \\
\hline 2017 & 111,6 & 5,4 ton & 59 \\
\hline 2018 & 111,6 & - & 47 \\
\hline 2019 & 111,6 & - & 44 \\
\hline 2020 & 111,6 & - & 44 \\
\hline
\end{tabular}

Source: North Toto Village office, 2020

The land area in North Toto Village did not increase at all in 2016 to 2020, which was 111.60 ha. Then the money production results were not recorded in the Village except for 2017 it was only 5.4 tons. The number of farmers for 2018-2020 has decreased, namely 44 farmers, because some of them moved villages/villages and some also died and resulted in a decline in farmers.

The problem that occurs is the income of rice farmers, namely the income they receive or what they produce is not in accordance with the production costs incurred. Based on the initial observations of farmers, it was stated that currently the price of fertilizer has increased but the selling price of rice has fallen so that the income earned is not in accordance with the costs that farmers incur.

\section{METHODOLOGY}

The research method used in this research is a quantitative approach. The data used are primary and secondary data. Data collection techniques were carried out by: 1) observation, 2) interviews, 3) questionnaires, 4) documentation. The population taken in the study were all farmers in the village of North Toto, Tilongkabila District, Bone Bolango Regency with a total sample of 44 farmers. The type of sampling method is a sampling technique when all members of the population are used as samples, this is done when the number of the population is relatively small or less than 100 respondents. Data were obtained through answers to questionnaires from rice farmers which became the object of research. The location of the research is in North Toto Village, Tilongkabila District, Bone Bolango Regency. The technique carried out on the data obtained from the questionnaire results and used to analyze the data in the form of numbers, the data is classified into categories using tables with the help of the SPSS program.

\section{RESULTS AND DISCUSSION}

\section{Regression Analysist}

This test was conducted to determine the relationship between the independent variable and the dependent variable, whether there is a positive or negative relationship. The following regression equation can be seen in 
table 2 with the results of the coefficients test on three variables, including price, land area and production costs to income.

Table 2. Coefficents

\begin{tabular}{|c|c|c|c|c|c|}
\hline \multirow[b]{2}{*}{ Model } & \multicolumn{2}{|c|}{$\begin{array}{c}\text { Unstandardized } \\
\text { Coefficients }\end{array}$} & $\begin{array}{l}\text { Standardized } \\
\text { Coeffi cients }\end{array}$ & \multirow[b]{2}{*}{$\mathrm{t}$} & \multirow[b]{2}{*}{ Sig. } \\
\hline & B & $\begin{array}{l}\text { Std. } \\
\text { Error }\end{array}$ & Beta & & \\
\hline (Constant) & 5,400 & 2,837 & & 1,903 & ,064 \\
\hline Total_H & 237 & 128 & 206 & 1,848 & ,072 \\
\hline Total_LI & ,682 & ,116 & ,628 & 5,866 & ,000 \\
\hline Total_Bp &,- 254 & ,075 &,- 356 & $-3,397$ & ,002 \\
\hline
\end{tabular}

Source: Data Processed (2020)

a) Constant value

The constant value of 5,400 means that if the price, land area, and production costs are 0 or constant then the income value is 5,400

b) Price (X1)

If the price variable increases by 1 percent while the land area and production costs remain constant, it can cause income $(Y)$ to decrease by 0.237 . Significant value $0.072>0.05$ it is known that it has a negative and insignificant effect on the income $(\mathrm{Y})$ of rice farmers. It is known that the high selling price has not fully been able to provide a large income for rice farmers because what is currently happening is that the selling price is sometimes high and sometimes low.

c) Land area (X2)

If the land area variable increases by 1 percent while prices and production costs remain constant, it can cause income $(Y)$ to increase by 0.682 . A significant value of $0.000<0.05$, it is known that a positive and significant effect on income $(\mathrm{Y})$ rice farmers. If the area of land owned by large farmers will have an impact on the amount of production it will also increase. This is because land area is an important factor in the production process to produce production which then affects the level of farmers' income.

d) Production cost (X3)

Variable production costs if there is an increase of 1 percent while the price and land area remain, it can cause income $(Y)$ to decrease by -0.254 . A significant value of $0.002>0.05$ thus has a negative and significant effect on the income of rice farmers in Toto Utara Village, Tilongkabila District, Bone Bolango Regency. From the results of research conducted as well as empirical evidence it is evident that production costs have an effect on income. In fact, in farming, there are two kinds of costs: cash costs, fees paid and non-cash costs.

\section{Coefficient of Determination $\left(R^{2}\right)$}

The results of the coefficient of determination test are used to measure how far the independent variables explain the dependent variable. The following is the calculation of the coefficient of determination in table 3.

Table 3. Model Summary

\begin{tabular}{|c|r|r|r|r|r|}
\hline Model & $\mathrm{R}$ & $\begin{array}{r}\mathrm{R} \\
\text { Square }\end{array}$ & $\begin{array}{r}\text { Adjusted } \\
\mathrm{R} \text { Square }\end{array}$ & $\begin{array}{r}\text { Std. Error } \\
\text { of the } \\
\text { Estimate }\end{array}$ & $\begin{array}{r}\text { Durbin- } \\
\text { Watson }\end{array}$ \\
\hline 1 &, $772^{\mathrm{a}}$ &, 596 &, 566 & 1,194 & 1,568 \\
\hline \multicolumn{4}{|c|}{ SourceL Data Processed (2020) }
\end{tabular}

Based on the results of the coefficient test, it shows that the percentage value (R Square) is 0.59 .6 and can be explained about the large percentage of the influence of the independent variables on the dependent, which means that the effect of the independent variable on the dependent is 59.6 percent while for the remaining 40.4 percent. influenced by other variables. 


\section{CONCLUSION}

1. Price has a negative and insignificant effect on the income of rice farmers, where the high and low selling prices cannot affect farmers' income because this is caused by several other factors, for example for production that is not in accordance with the price offered.

2. Land area has a positive and significant effect on the income of rice farmers, where every additional land area that occurs will increase the income of farmers.

3. Production costs have a negative and significant effect on the income of rice farmers, where every increase in production costs will affect income. If only the production costs rose such as seeds, fertilizers, pesticides, but the income obtained did not match the costs incurred by the farmers.

\section{REFERENCES}

Amir Machmud. (2016). Perekonomian Indonesia Pasca Revormasi. Erlangga.

Badan Pusat Statistika. (2020). Luaspanen, Produktivitas, dan Produksi.

Gorontalo ANTARA. (2020). Produksi padi di Bone Bolango meningkat di masa pandemi. https://gorontalo.antaranews.c om/berita/143208/produksi- padi-di-bone-bolango- meningkat-dimasa-pandemi

Kuncoro, Mudrajat. (2010). MasalahKebijakan dan Politik: Ekonomika Pembangunan. Erlangga. 